\title{
Influence of post-annealing in sulfur atmosphere on thermally evaporated $\beta-\operatorname{In}_{2} S_{3}$ films
}

\author{
S. Rasool ${ }^{\text {a }}$ K. Saritha ${ }^{\text {a }}$, K.T. Ramakrishna Reddy ${ }^{\text {a,* }}$, M.S. Tivanov ${ }^{\text {b }}$, V.F. Gremenok ${ }^{c}$ \\ ${ }^{a}$ Department of Physics, Sri Venkateswara University, Tirupati 517 502, Andhra Pradesh, India \\ ${ }^{\mathrm{b}}$ Faculty of Physics, Belarusian State University, Nezavisimosti 4 av., 220030 Minsk, Belarus \\ ' Scientific and Practical Materials Research Centre, National Academy of Sciences, 220072 Minsk, Belarus
}

\section{A R T I C L E I N F O}

\section{Article history:}

Received 27 December 2019

Received in revised form 15 August 2020

Accepted 19 August 2020

Available online 24 September 2020

\section{Keywords:}

$\mathrm{In}_{2} \mathrm{~S}_{3}$ films

Vacuum evaporation

Sulfur annealing

Structure

Band gap energy

\begin{abstract}
A B S T R A C T
Indium sulfide $\left(\mathrm{In}_{2} \mathrm{~S}_{3}\right)$ is an n-type semiconductor with wide bandgap energy $(2.2-2.7 \mathrm{eV})$ and is currently used as buffer/window layer in thin film solar cells as an alternative to toxic CdS. In the present study, $\mathrm{In}_{2} \mathrm{~S}_{3}$ thin films were deposited on soda lime glass substrates using thermal evaporation technique at different substrate temperatures, $T_{\mathrm{s}}=200^{\circ} \mathrm{C}-350^{\circ} \mathrm{C}$. Further, all the as-deposited films were annealed in sulfur ambient at $250{ }^{\circ} \mathrm{C}$ for $1 \mathrm{~h}$. The structural, compositional and optical properties of annealed $\operatorname{In}_{2} \mathrm{~S}_{3}$ films were analyzed using GIXD, EDS and Photon RT spectrophotometer respectively. All the annealed films exhibited polycrystalline nature with improved crystallinity and high optical transmittance in the visible region. Moreover, the as-deposited films were sulfur deficient whereas in annealed layers the S/In ratio was increased due to sulfur annealing. Therefore, annealing of $\operatorname{In}_{2} \mathrm{~S}_{3}$ films in sulfur atmosphere enhanced the quality of the films. Among all the as-deposited and annealed films, the layers grown at $T_{\mathrm{s}}=300^{\circ} \mathrm{C}$ followed by annealing at $250^{\circ} \mathrm{C}$ have shown better structural and optical properties than the other films.

(c) 2019 Elsevier Ltd. All rights reserved.

Selection and peer-review under responsibility of the scientific committee of the 3rd International Conference on Solar Energy Photovoltaics.
\end{abstract}

\section{Introduction}

Now-a-days, researchers are showing great interest on environmental friendly materials to develop low cost solar cells. $\operatorname{In}_{2} \mathrm{~S}_{3}$ is a potential candidate for its use as a window/buffer layer in thin film solar cell applications due to its n-type conductivity, wide band gap energy (2.1-3.1 eV), good photoconductive response and less toxicity compared to CdS [1-3]. Generally, the properties of thin films can be enhanced by annealing, chemical treatment and doping or alloying processes. The main purpose of annealing is to improve the quality of thin films by enhancing the nucleation process, which consequently increases the grain size with reduced defects. In case of $\operatorname{In}_{2} \mathrm{~S}_{3}$ films deposited at higher temperatures, the sulfur deficiency is a common phenomenon occurred due to re-evaporation of sulfur from the film surface owing to its high volatility and vapour pressure. To overcome this problem, sulfur annealing is an apt approach to maintain stoichiometric composition of $\operatorname{In}_{2} \mathrm{~S}_{3}$ films. As per literature survey, despite the availability

\footnotetext{
* Corresponding author.

E-mail address: ktrkreddy@gmail.com (K.T. Ramakrishna Reddy).
}

of numerous reports on annealing effect on $\operatorname{In}_{2} \mathrm{~S}_{3}$ films, a very few reports are available on the effect of sulfur annealing on $\operatorname{In}_{2} \mathrm{~S}_{3}$ films $[4,5]$. Therefore in the present study, thermally evaporated $\operatorname{In}_{2} S_{3}$ films were post annealed in sulfur atmosphere and the structural, compositional and optical properties of the layers were investigated using various techniques.

\section{Experimental details}

$\mathrm{In}_{2} \mathrm{~S}_{3}$ thin films were deposited onto soda-lime glass substrates using thermal evaporation technique (Hind Hi Vac BC 300 box coater) at different substrate temperatures, $T_{\mathrm{S}}=200-350{ }^{\circ} \mathrm{C}$. $\mathrm{In}_{2} \mathrm{~S}_{3}$ powder (Sigma Aldrich $99.999 \%$ ) was used as source material and kept at a distance of $14 \mathrm{~cm}$ from the glass substrates. The powder was evaporated at a rate of $15 \AA / s$. The grown $\operatorname{In}_{2} \mathrm{~S}_{3}$ films were of $\sim 500 \mathrm{~nm}$ thick measured using a quartz crystal thickness monitor. Further, the as-deposited layers were annealed under sulfur atmosphere $\left(2 \times 10^{-2}\right.$ mbar $)$ using two zone tubular vacuum furnace at $250{ }^{\circ} \mathrm{C}$ for $60 \mathrm{~min}$. The as-deposited as well as annealed $\mathrm{In}_{2} \mathrm{~S}_{3}$ films were characterized using various techniques. The structural details of the films were investigated using Ultima IV X-ray 
diffractometer with $\mathrm{Cu} K \alpha$ radiation source $(\lambda=1.5406 \AA)$ in grazing incidence X-ray diffraction (GIXD) geometry at 1 degree of grazing angle. The layer composition was analyzed by energy dispersive spectroscopy (EDS) with the aid of an INCA energy analyzer attachment (Oxford Instruments). The optical transmission and reflection spectra of the films were measured using Photon RT spectrophotometer (Essent Optics).

\section{Results and discussion}

\subsection{Structural analysis}

Fig. 1(a) and (b) shows the GIXD patterns of as-deposited and annealed $\operatorname{In}_{2} \mathrm{~S}_{3}$ films. From Fig. 1(a), the films deposited at lower substrate temperatures $\left(T_{\mathrm{S}}=200^{\circ} \mathrm{C}\right.$ and $\left.250^{\circ} \mathrm{C}\right)$ showed amorphous nature due to insufficient thermal energy provided to the substrate as a result the ad-atoms could not move freely on the substrate surface, which causes the growth of many nuclei without surface diffusion [6]. Further increase of $T_{\mathrm{s}}$ to $300^{\circ} \mathrm{C}$ and $350^{\circ} \mathrm{C}$, the films exhibited polycrystalline nature with poor crystallinity and had mixed phases of cubic and tetragonal $\beta-\mathrm{In}_{2} \mathrm{~S}_{3}$. The films changed from amorphous nature to polycrystalline with increase of $T_{\mathrm{s}}$ due to increase of ad-atom mobility that stimulated the growth of crystallites in different orientations. Moreover, the existence of mixed phases of cubic and tetragonal $\beta-\mathrm{In}_{2} \mathrm{~S}_{3}$ is a common phenomenon observed in thin film formation irrespective of the deposition techniques used, which was reported in several works [7-9]. All as-deposited films required post-annealing treatment to improve the crystalline quality as well as other physical properties. Therefore, all the as-deposited layers were annealed at $250{ }^{\circ} \mathrm{C}$ under sulfur ambient for $60 \mathrm{~min}$. The annealed layers showed bet- ter crystallinity than the as-deposited films and had only cubic phase of $\beta-\mathrm{In}_{2} \mathrm{~S}_{3}$ (JCPDS 65-0459) (see Fig. 1(b)). Further, the size of coherent scattering region $(L)$ and the lattice deformation $(\varepsilon)$ of the films were calculated using the appropriate formulae as reported in the literature [10] and the obtained values were tabulated in Table 1. From Table 1, it is observed that ' $L$ ' value increased in annealed films, which might be due to the coalescence of smaller nuclei or neighboring smaller crystallites. The crystallinity of the films improved after annealing due to the sufficient thermal energy available for recrystallization and grain growth with reduced defects.

\subsection{Composition analysis}

Fig. 2 shows the variation of S/In ratio for as-deposited and annealed $\operatorname{In}_{2} \mathrm{~S}_{3}$ films. It is observed that $\mathrm{S} / \mathrm{In}$ ratio decreased from 1.21 to 1.01 with increase of substrate temperature $\left(200{ }^{\circ} \mathrm{C}\right.$ $350{ }^{\circ} \mathrm{C}$ ) in the as-grown films due to re-evaporation of sulfur from the films, owing to its high volatility and vapour pressure, whereas for annealed layers, the S/In ratio is increased and varied in the range, $1.53-1.66$. The films deposited at $T_{\mathrm{s}}=300{ }^{\circ} \mathrm{C}$, after sulfur annealing showed $\mathrm{S} / \mathrm{In}$ ratio of 1.53 , which is close to bulk value (1.49) of $\operatorname{In}_{2} \mathrm{~S}_{3}$ powder and the rest of the annealed films contained higher S/In ratio greater than 1.60 . The increment of sulfur content in annealed films is due to rapid reaction of sulfur vapours with indium that led to the formation of stoichiometric $\beta$ - $\operatorname{In}_{2} S_{3}$ phase. A similar variation of $S / I n$ values was reported by Bouabid et al. for flash evaporated $\operatorname{In}_{2} \mathrm{~S}_{3}$ films annealed at $300^{\circ} \mathrm{C}$ under sulfur atmosphere [4]. Moreover, the change in S/In ratio can affect the optical band gap and other properties of the $\operatorname{In}_{2} \mathrm{~S}_{3}$ layers.
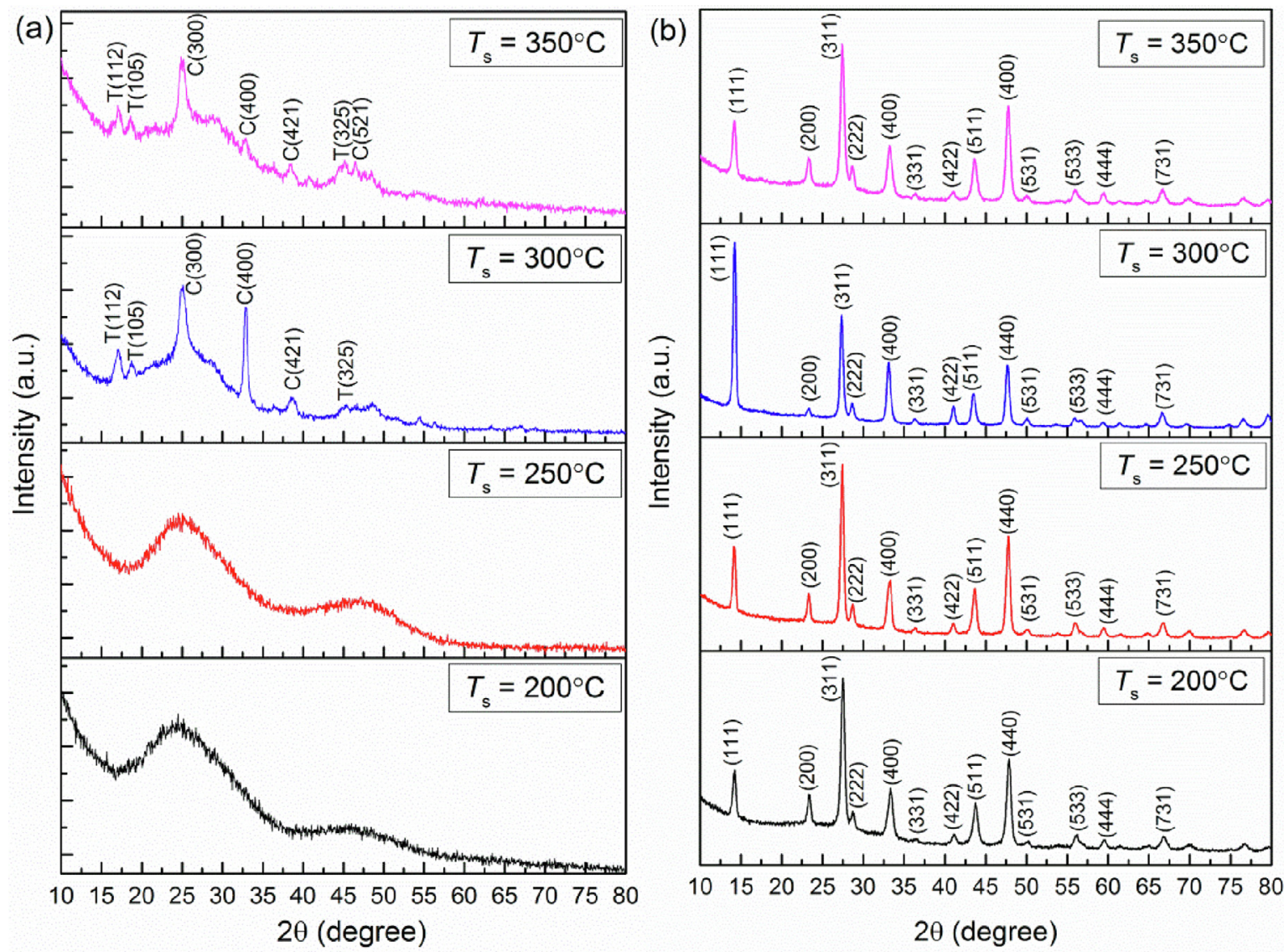

Fig. 1. GIXD patterns of $\operatorname{In}_{2} \mathrm{~S}_{3}$ films (a) befor and (b) after annealing at $250{ }^{\circ} \mathrm{C}$. 
Table 1

Structural parameters of $\operatorname{In}_{2} S_{3}$ films.

\begin{tabular}{|c|c|c|c|c|c|c|c|c|}
\hline \multirow[b]{2}{*}{$T_{\mathrm{s}}\left({ }^{\circ} \mathrm{C}\right)$} & \multicolumn{4}{|c|}{ Before annealing } & \multicolumn{4}{|c|}{ After annealing } \\
\hline & 200 & 250 & 300 & 350 & 200 & 250 & 300 & 350 \\
\hline$(h k l)$ & - & - & $(300)$ & $(300)$ & (311) & $(311)$ & $(111)$ & (311) \\
\hline $\mathrm{L}(\mathrm{nm})$ & - & - & 3.0 & 8.7 & 13.7 & 15.0 & 15.2 & 12.7 \\
\hline$\varepsilon \times 10^{-2}$ & - & - & 5.5 & 1.9 & 1.1 & 1.0 & 1.0 & 1.2 \\
\hline
\end{tabular}

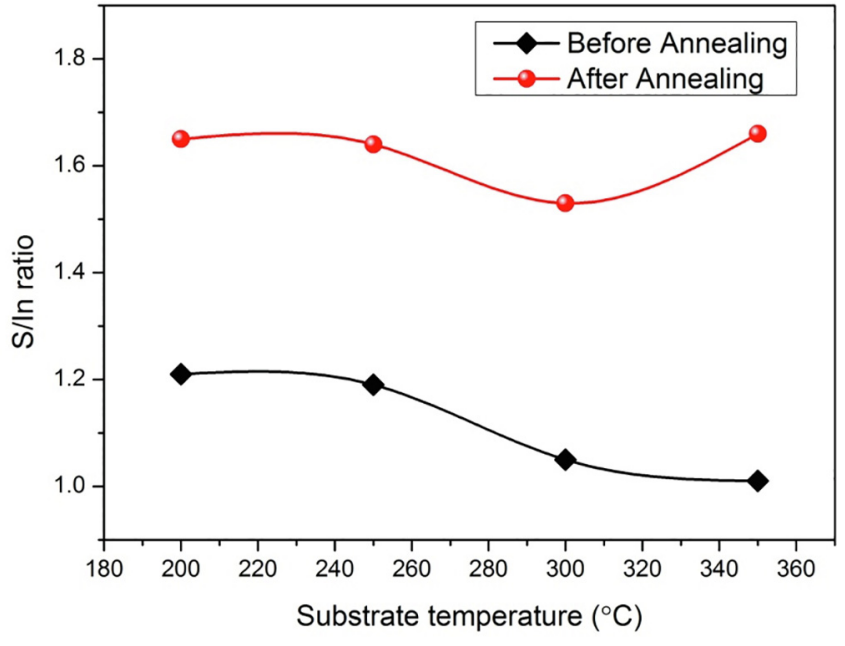

Fig. 2. Variation of $S /$ In ratio with substrate temperature.

\subsection{Optical studies}

Fig. 3(a) and (b) shows the transmission spectra of as-deposited and annealed $\mathrm{In}_{2} \mathrm{~S}_{3}$ films. After annealing, all the films showed high trasmittance $(>60 \%)$ in the visible region compared to as-deposited layers and the interference fringes in the transmittance spectra indicates good homogeneity and uniformity of the films. The optical transmittance was improved for annealed films because of improved crystallinity.

The optical band gap energy of the layers was evaluated from the following Tauc relation for direct allowed transitions [6], where $\mathrm{h} v$ is photon energy and $A$ is a constant related to the effective mass of the material.

$(\alpha h v)^{2}=A\left(h v-E_{g}\right)$

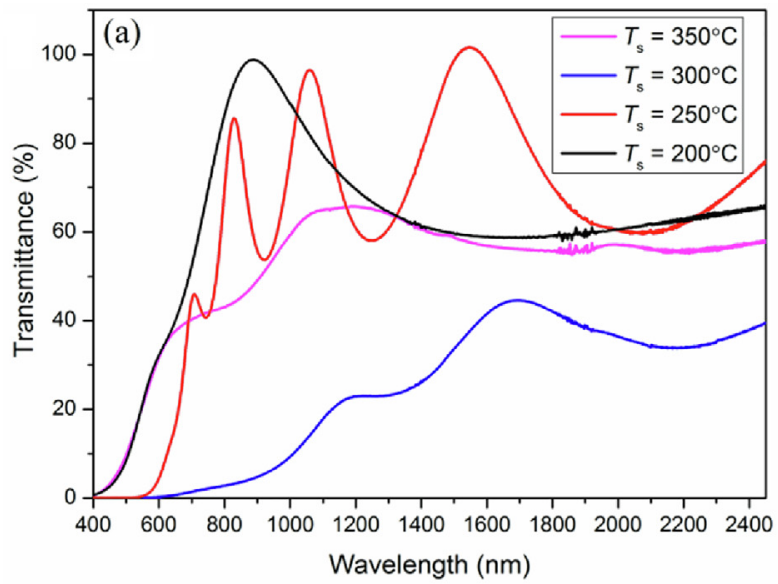

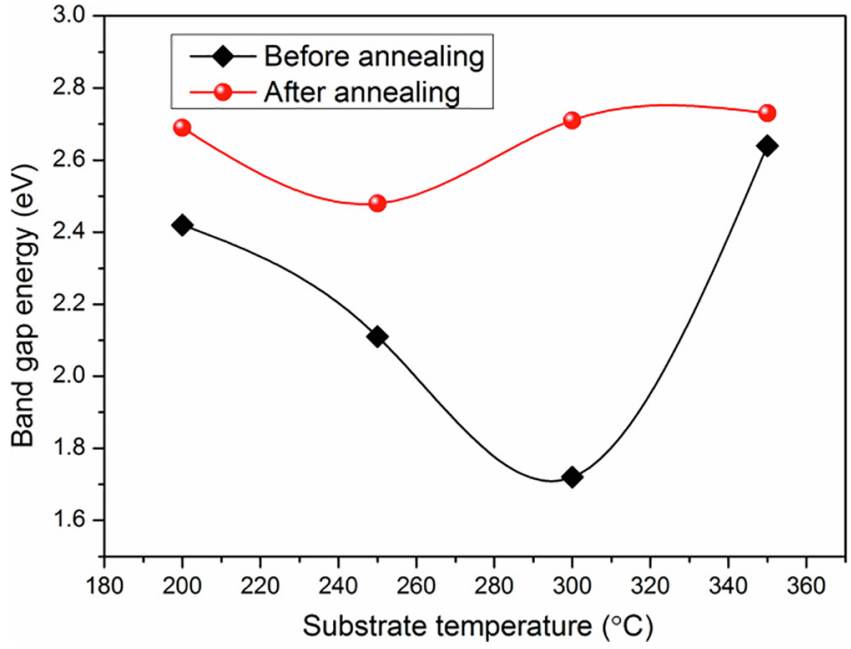

Fig. 4. Variation of band gap energy with substrate temperature.

The evaluated band gap energy values of the as-deposited layers was initially decreased from $2.42 \mathrm{eV}$ to $1.72 \mathrm{eV}$ upto $T_{\mathrm{S}}=300{ }^{\circ} \mathrm{C}$ and then increased to $2.64 \mathrm{eV}$ due to change in composition and structural defects of the layers, whereas for annealed layers, the band gap energy was higher than the as-deposited layers and varied in the range, $2.48-2.73 \mathrm{eV}$. The rise in band gap energy upon annealing was due to better stoichiometry, improved crystalline quality and less defects of the layers compared to asgrown layers [11]. Fig. 4 shows the variations of band gap energy values of the layers with the substrate temperature.

\section{Conclusions}

$\mathrm{In}_{2} \mathrm{~S}_{3}$ thin films were deposited at different substrate temperatures using thermal evaporation technique. Further, all the films

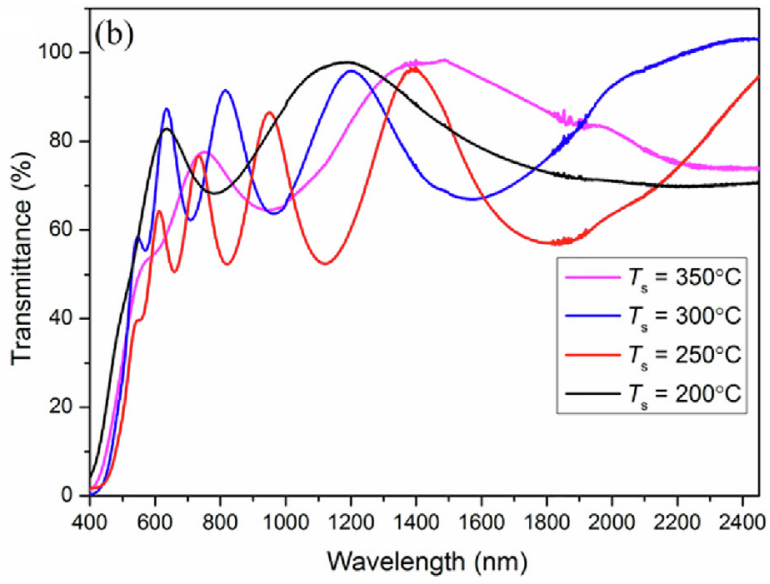

Fig. 3. Transmittance of $\operatorname{In}_{2} S_{3}$ films (a) befor and (b) after annealing at $250{ }^{\circ} \mathrm{C}$. 
were annealed at $250{ }^{\circ} \mathrm{C}$ in sulfur atmosphere. The structural, composition and optical properties of as-deposited and sulfur annealed films were investigated. From the results, it is concluded that the post-annealing treatment of the layers grown at $300^{\circ} \mathrm{C}$ in sulfur ambient improved the physical properties of as-deposited films.

\section{CRediT authorship contribution statement}

S. Rasool: Conceptualization, Methodology, Formal analysis, Investigation, Data curation, Writing - original draft. K. Saritha: Resources, Validation, Visualization. K.T. Ramakrishna Reddy: Writing - review \& editing, Supervision, Project administration. M.S. Tivanov: Investigation, Project administration. V.F. Gremenok: Formal analysis.

\section{Declaration of Competing Interest}

The authors declare that they have no known competing financial interests or personal relationships that could have appeared to influence the work reported in this paper.

\section{Acknowledgements}

One of the authors, S. Rasool thanks the University Grants Commission (UGC), New Delhi for the financial assistance via the "UGC-BSR fellowship".

The authors, Prof. K.T. Ramakrishna Reddy and Prof. M.S. Tivanov wish to acknowledge the Dept. of Science and Technology, Govt. of India (Grant no.: DST/INT/BLR/P-30/2019) and the State Committee on Science and Technology of the Republic of Belarus
(Grant no.: F19INDG-008) for funding via India-Belarus joint programme.

\section{References}

[1] M.A. Mughal, R. Engelken, R. Sharma, Progress in indium (III) sulphide $\left(\mathrm{In}_{2} \mathrm{~S}_{3}\right)$ buffer layer deposition techniques for CIS, CIGS and CdTe-based thin film solar cells, Sol. Energy 120 (2015) 131.

[2] J. George, K.S. Joseph, B. Pradeep, T.I. Palson, Reactively evaporated films of indium sulfide, Phys. Status Solidi A 106 (1988) 123.

[3] E.B. Yousfi, B. Weiberg, F. Donsanti, P. Cowache, D. Lincot, Atomic layer deposition of zinc oxide and indium sulfide layers for $\mathrm{Cu}(\mathrm{In}, \mathrm{Ga}) \mathrm{Se} 2$ thin-film solar cells, Thin Solid Films 387 (2001) 29.

[4] K. Bouabid, A. Ihlal, Y. Amira, A. Sdaq, A. Outzourhit, G. Nouet, Effect of annealing on $\mathrm{In}_{2} \mathrm{~S}_{3}$ thin films prepared by flash evaporation, Eur. Phys. J. Appl. Phys. 40 (2007) 149.

[5] C. Sanz, C. Guillén, J. Herrero, Annealing of indium sulfide thin films prepared at low temperature by modulated flux deposition, Semicond. Sci. Technol. 28 (2013) 015004.

[6] Z.Y. Zhong, E.S. Cho, S.J. Kwon, Effect of substrate temperature on evaporated In2S3 thin film buffer layer for Cu(In,Ga)Se2 solar cells, 547 (2013) 22.

[7] N. Revathi, P. Prathap, K.T. Ramakrishna Reddy, Thickness dependent physical properties of close space evaporated In2S3 films, Solid State Sci. 11 (2009) 1288.

[8] J. Raj Mohamed, L. Amalraj, Effect of precursor concentration on physical properties of nebulized spray deposited $\operatorname{In}_{2} \mathrm{~S}_{3}$ thin films, J. Assian Ceram. Soc. 4 (2016) 357.

[9] M.G. Sandoval-Paz, M. Sotelo-Lerma, J.J. Valenzuela-Ja’uregui, M. FloresAcosta, R. Ramirez-Bon, Structural and optical studies on thermal-annealed $\mathrm{In}_{2} \mathrm{~S}_{3}$ films prepared by the chemical bath deposition technique, Thin Solid Films 472 (2005) 5.

[10] S. Rasool, K. Saritha, K.T. Ramakrishna Reddy, M.S. Tivanov, A.V. Trofimova, S.E. Tikoto, L. Bychto, A. Patryn, M. Maliński, V.F. Gremenok, Effect of annealing on the physical properties of thermally evaporated $\operatorname{In}_{2} \mathrm{~S}_{3}$ thin films, Curr. Appl. Phys. 19 (2019) 108.

[11] S.P. Nehra, S. Chander, A. Sharma, M.S. Dhaka, Effect of thermal annealing on physical properties of evaporated $\mathrm{In}_{2} \mathrm{~S}_{3}$ buffer layer for eco-friendly photovoltaic applications, Mater. Sci. Semicond. Proc. 40 (2015) 26. 